\title{
Welfare Practice in Response of Child Neglect: Reconstruction and Analysis of the Discourses on Family, Childrearing, and Motherhood
}

\author{
Margot Vogel Campanello, Susanna Niehaus, Delia Pisoni, Michèle Röthlisberger, Tanja Mitrovic
}

Institute of Social Work and Law, Lucerne University of Applied Sciences and Arts, Lucerne, Switzerland

Email: margot.vogel@hslu.ch

How to cite this paper: Vogel Campanello, M., Niehaus, S., Pisoni, D., Röthlisberger, M., \& Mitrovic, T. (2021). Welfare Practice in Response of Child Neglect: Reconstruction and Analysis of the Discourses on Family, Childrearing, and Motherhood. $A d$ vances in Applied Sociology, 11, 34-47. https://doi.org/10.4236/aasoci.2021.111004

Received: December 11, 2020

Accepted: January 26, 2021

Published: January 29, 2021

Copyright $\odot 2021$ by author(s) and Scientific Research Publishing Inc. This work is licensed under the Creative Commons Attribution International License (CC BY 4.0).

http://creativecommons.org/licenses/by/4.0/

(c) (i) Open Access

\begin{abstract}
Child neglect is an ongoing social problem, estimated to affect 5 - 10 per cent of children. The term neglect describes a behavior that deviates from an ideal norm. However, both the form of this ideal norm and the definition of deviation depend on contemporary discourses and scientific positions. Historically, it has been more frequently poor families and single mothers who have been disciplined for child neglect by the state, whilst their economic situation was marginalized. Parallel current findings raise questions regarding how these discourses form, how they influence decision-making processes, and whether a continuity can be ascertained in measures of social disciplining. Our ongoing research project on welfare practice in response of child neglect aims to reconstruct and analyze current discourses on family, childrearing, and motherhood in the context of child neglect. Taking a multi-perspectival approach, it will analyze and compare the expert discourse, the politi$\mathrm{cal} /$ public discourse, and the perspective of affected mothers across two different time periods in five selected Swiss cantons. Preliminary findings indicate that gender categories, especially motherhood, continue to be of great importance. On the basis of a first analysis of casefiles, one could speak of a "motherism": in case processing and in the course of the case, responsibility is attributed to the mother, and social and pedagogical contexts are neglected, even the financial situation seems to be given less importance. Instead, the willingness to cooperate often seems to be a key factor in deciding on further interventions. Furthermore, there are indications that in decision-making processes with far-reaching consequences, legal arguments are preferred while childrearing aspects are neglected. It can also be noted that normative and sometimes stigmatizing statements do not seem to belong to the past. In this article, we will give insight into the research design and first findings and discuss the necessity of reflecting on the images of family, childrearing, and
\end{abstract}


motherhood in light of the rapid social changes in the spheres of family, motherhood, and fatherhood.

\section{Keywords}

Child Neglect and Protection, Family, Childrearing, Motherhood, Gender

\section{Introduction}

Child neglect is an ongoing social problem. It is estimated that still $5-10$ per cent of children suffer from it (Bericht des Bundesrates in Erfüllung des Postulats Fehr, 2012: p. 18). Child neglect, defined as the persistent or repeated failure of caregivers to provide the necessary care to ensure a child's mental and physical welfare, is not a new social phenomenon. Even as social work first became established, forms of neglect were already being described as a necessary work field, for example under the German term Verwahrlosung. This German term covers all forms of neglect, but also inadequate childrearing as well as connotations of depravity and moral turpitude. Verwahrlosung became either an almost unchangeable or completely unchangeable family characteristic that legitimized interventions in families along with the compulsory placement of children and adolescents in foster care (see Galm et al., 2010: pp. 8ff). The term neglect (Vernachlässigung) describes a behavior that deviates from an ideal norm. However, both the form of this ideal norm and the definition of deviation depend on contemporary discourses and scientific positions. Whereas from the mid-18th to the mid-19th century, the focus was on protection through the provision of physical care, the focus shifted in the second half of the 19th century to childrearing neglect. At the beginning of the 20th century, the majority of German-language publications addressed the topic of Verwahrlosung (see Aichhorn, 1951; Herriger, 1987; Rühle, 1971), whereas today the German term Vernachlässigung is predominant. Common to both terms is that the way these forms are described, the terms applied, and the naming of possible causes all vary across time and disciplines. Historically, it has been more frequently poor families and (single) mothers who have been disciplined for child neglect by the state. Nonetheless, their economic situation was marginalized, and the state took their childrearing behavior as an important criterion for legitimizing its actions. The situation today reveals parallels to these findings. Therefore, the present project aims to reconstruct and analyze current discourses on family, childrearing, and motherhood in the context of child neglect. This raises questions regarding how these discourses form, how they influence decision-making processes, and whether a continuity can be ascertained in measures of social disciplining.

In this article, we will give insight in design and first findings of our ongoing research project "Welfare practice in response of child neglect: Reconstruction and analysis of discourses on family, childrearing and motherhood", which is 
conducted at the Lucerne University of Applied Sciences and Arts, implemented within the framework of the Swiss National Science Foundation's Research program 76 "Welfare and Coercion-Past, Present and Future", and carried out between October 2018 and September 2021.

\subsection{Historical Background}

In German, the two terms "Vernachlässigung" [neglect] and "Verwahrlosung" [more emphasis on depravity] represent an "unresolved definition problem" (Herriger, 1987: p. 11, translated). They describe a state or behavior that is appraised as a deviation from some ideal norm. This ideal norm is the concept of normality against which a behavior is measured, and it is the constitution of this benchmark normality that is in need of explanation. Both German terms simultaneously reveal that more precise definitions of their content depend essentially on the approaches taken within specific disciplines and the given discourses in society (see Herriger, 1987; Ramsauer, 2000). ${ }^{1}$ In Switzerland, the concept of "Verwahrlosung" became anchored legally in the Swiss Civil Code (ZGB) in 1912. Control of parents and interventions in their childrearing were subsequently legitimized for the protection of the child. Currently, the protection of the child is measured legally in terms of the child's well-being. However, the ZGB does not define the meaning of the term child's well-being. Criteria can be found indirectly in the childrearing concept set down in Art. 301 and 302 ZGB and through the specification of developmental goals of encouraging autonomy, proficiency, and well-being (see Affolter-Fringeli \& Vogel, 2016).

At the time of the introduction of the ZGB, the legal status of the wife in relation to her husband was also changed. The traditional patriarchal rights over wives (legal guardian) in cantonal codes were abolished and responsibility for rearing children was transferred to both parents. This also raised expectations regarding women as childrearers, and it changed how civil authorities perceived them (see Ramsauer, 2000: pp. 280 f). Interventions such as foster care and the suspension of parental authority and care because of "Verwahrlosung" were justified in different ways depending on which discourse was predominant: Ramsauer, for example, describes how in 1914, the main reason for intervening in approximately one-quarter of the cases of removal of children in Zurich was named as childrearing problems, and this was followed by parental personality characteristics. In 1934, although childrearing problems continued to be a reason for intervening, the "Geisteszustand" [mental state] of the parents had gained a more important status among justifications for the removal of children (see op. cit., pp. 219 ff). This offers a good illustration of how contemporary discourses and scientific positions influenced welfare practices. Nonetheless, childrearing remained an important reason for interventions. Over the course of ${ }^{1}$ Ramsauer (2000) condenses the term "Verwahrlosung" by applying three interpretation models (social-deterministic, eugenic-psychiatric, and pedagogical) that were predominant in Switzerland between 1900 and 1945. Herriger (1987), in contrast, defines "Verwahrlosung" more closely in psychopathological, pedagogical, and sociological terms while simultaneously pointing to the entanglement of the disciplines in the sense of Kuhn's paradigm shift. 
the 20th century, a scientification of the discourse through educational science led to (maternal) childrearing being judged according to pedagogical concepts (see Ramsauer, 2000: pp. 222 ff).

Historically intervening in the family in cases of "Verwahrlosung" was viewed as a solution to what was known as the "Soziale Frage" [social issue] (see Ramsauer, 2000; Rietmann, 2013). It was particularly the poor who were exposed to such normalization and adjustment pressures (see Atzbacher, 2010; Bühler et al., 2019; Hauss, 2012; Ramsauer, 2000), but also women who did not comply with the prevailing sexual morals (see Jenzer, 2014: p. 162). They were described as "morally endangered" or "fallen" girls. Legal incapacitation was the answer to an "immoral way of life". Abolitionist federations campaigned to limit sexuality to marriage and strove towards a social disciplining of such women. These women mostly had a lower-class social background (see Jenzer, 2014, on administrative treatment based on "Liederlichkeit" [licentiousness]; see also Rietmann, 2013). As a result, hardly any attention was paid to the economic situation of either these families or unmarried women (see Hauss, 2012: p. 44).

\subsection{Research Interest}

Despite increasing knowledge and the efforts to professionalize social work, current statistics on child neglect reveal a parallel development to the historical findings: poor children are over-represented among the neglected by a ratio of 7:1 (Drake \& Jonson-Reid, 2014: p. 133). ${ }^{2}$ Regarding the gender distribution, we find according to the statistic of the Swiss Society of Paediatrics "a markedly higher proportion of women among the offenders than men" (Schweizerische Gesellschaft für Pädiatrie SGP, 2017: p. 2, translated). ${ }^{3}$ Our own explorative study of child neglect examined the living and working conditions of so-called "neglectful families". Results showed that all these families were living in precarious social and working conditions. Working families were employed in the low wage sector, and some of them under atypical working conditions; they had low educational and vocational qualifications, and thereby poor prospects of social mobility. They were also living in precarious financial conditions (in debt and/or receiving welfare payments). Such structural conditions make it far more difficult to rear and care for children. The living and working situation described here was even more extreme for single mothers. Finally, one-parent families revealed a notable absence of fathers. Although the majority of these fathers were in contact with their families, they shared neither financial nor childrearing responsibilities. Social work focuses on the responsibility of the mothers, and it mostly supports these mothers in rearing their children. This marginalizes the socio-structural situation of these families (Vogel Campanello, 2018, 2019).

Against this background, it is necessary to ask how far precarity can be viewed ${ }^{2}$ It can be assumed that part of this marked difference is attributable to the responsible authorities focusing and reporting more strongly on poor families (see op. cit., pp. $134 \mathrm{f}$ ).

${ }^{3}$ In the last two years (statistics 2018 and 2019), the gender distribution of perpetrators has become more even. At this point it remains open to what extent this has to do with a more gender-sensitive data collection or with actual changes in the gender ratio. 
as a new expression of the social issue (see Castel \& Dörre, 2009; Hammerschmidt \& Sagenbiel, 2011). Lutz, 2014 reports how an increase in symptoms of social exhaustion can be observed at the lower end of society, and that this is being "discussed and denounced as not only neglect but also a failure to take responsibility for their children" (p. 13, translated). Further we ask how far care, and above all, child neglect have primarily female connotations (see Turney, 2000); how far state interventions in the family can still be justified as a response to inadequate childrearing; and how far one can trace a continuity in socially disciplining mechanisms. To explore these questions, our project aims to analyze the characteristics, mechanisms, and effects of Swiss welfare practice in the context of child neglect, and to identify the potential causes of welfare practices that either violate or protect integrity. It will do this by analyzing current discourses on family, childrearing, and motherhood in the context of child neglect and relating these discourses to historical trends. Family is hereby understood as a committed care context, a private way of living. As a result, the concept has to be conceived independently from the specific lifestyle of marriage and consanguinity (see Jurczyk, 2014: p. 171). We define childrearing as deliberately influencing persons with the aim of imparting knowledge, behaviors, and skills (Gudjons, 1995: pp. 195f). In particular, we focus on discourses on family and childrearing, and on how these have varied due to social change. Finally, Motherhood is conceived as a socially defined status of a "socially particularly gendered care relationship construction" (Tolasch, 2016: p. 44, translated), as well as a relationship between mother and child (see Kortendiek, 2010: pp. 442ff). The project focuses on motherhood and not on parenthood in general, in order to take sufficient account of gender differences. We ask how the affected mothers view welfare practice, and how their view differ from that in the expert discourses. Our intention is therefore to trace current and historical expert discourses as well as political and public ones, and to ask how these discourses influence decision-making processes.

\section{Theoretical Research Perspective and Working Hypotheses}

Combined with sociological analyses of current transformation processes (see Aulenbacher, 2009; Castel, 2008; Castel \& Dörre, 2009), the underlying theoretical research perspective for the project is discourse analysis (see Fegter et al., 2015; Keller, 2011b; Kessl, 2011). Together with constructivist approaches, discourse analysis posits that reality is conveyed only through representations and that no knowledge is possible without categories, interpretation, and ideology (see König, 2014: p. 163). In this sense, reality is constituted through the use of speech in social acts and is formed through institutionally stabilized rules and orders of discourse (see Keller, 2011b: p. 125). Drawing on Foucault, 2015, we understand discourse as a set of dispersed statements appearing in different places that are or have been formed according to the same pattern or systems of rules and then constitute objects (see Keller, 2011a: p. 46). Social practices and 
speech acts are understood as constituting and standing in interaction with the symbolic order. Discourses thereby take a dialectic relation to the social structure that forms the context (see Keller, 2011a: p. 29). At the same time, they are historical and can be understood only in relation to their context (see op. cit., p. 30). In other words, the date/text needs to be linked systematically to the social conditions of the phenomenon, the ideologies, and the power relations. Interpretations always have to be understood as dynamic and open to new contexts (see ibid.). The focus is on the authorization and exclusion criteria in discourses, on the practices through which discourses form subjects ("subjectivisations"), that is, on the mechanisms of normalization and disciplining that individuals constitute as subjects. The assessment of the object results from the relation between formations of knowledge, balances of power, and subjectivisations (see Fegter et al., 2015: p. 10). Whereas constructivist approaches ask about the contexts that justify the meaning of practices, discourse analysis focuses on the constitution of social practices. It asks which self-understandings and balances of power constitute the logic of events and how patterns of perception and action and their relevance are determined, and meaning is generated. The aim is to work out the systems of rules that structure what is said. There is particular interest in the normative utterances that construct the effect of symbolic order and in how certain norms regulate the practice of social actors (see König, 2014: p. 164).

Taking this theoretical research perspective, the project is based on the following working hypotheses: ${ }^{4}$ specific role models of family, childrearing, and motherhood constitute expert discourses and contribute to both the regulation of practice and the constitution of the subjects. The effect of this discourse can be seen in the subjective perspective of those addressed in that their own constitution of family, childrearing, and motherhood is oriented towards symbolic orders. At the same time, the social practices of those affected as well as the politi$\mathrm{cal} /$ public discourse and the role models these express affect the constitution of expert discourses. The role models inherent to the discourse are the basis for decisions and are not made explicitly visible.

The aim of the research project is to generate more knowledge about the decision-making processes (e.g. Fluke et al., 2020; Munro, 2019; Pomey, 2017; Taylor \& Whittaker, 2020) and the impact of normative images (e.g. Alberth \& Bühler-Niederberger, 2017; Bauer \& Wiezorek, 2017; Björkhagen Turesson, 2020; Cyprian \& Heimbach-Stein, 2003; Pomey, 2015; Richter, 2009; Tolasch \& Seehaus, 2017), and thereby gain more knowledge about the need to reform the practice of social work so that it will support its clients and not run the risk of increasing their vulnerability through inappropriate interventions. Accordingly, the anticipated results will be particularly significant for officials in the Kindesund Erwachsenenschutzbehörde (KESB) [Children and adult protection authority], social work professionals, interested academic circles, and the families af ${ }^{4}$ In the sense of the inductive research logic of grounded theory, hypotheses and concepts are determined during the research process and tested deductively on the collected data (see Strauss, 1996). 
fected by state interventions.

\section{Methodical Approach and Research Methods}

The study has a multi-perspectival approach (a broad sample of media and political documents, files of cases of child neglect, non-participant observation of the decision-making sessions, expert interviews, problem-centered interviews with mothers and protocols, conceptual definitions of professional institutions). All data are collected in five Swiss cantons selected to differ as far as possible in their structural characteristics (referring to Braun, 1970) ${ }^{5}$. The study is addressing the years 2009/2010 and 2018/2019. These time periods have been selected to allow a comparison of the reconstructed discourses before and after the reform of child protection in 2013 and the professionalization of the guardianship authorities it announced through setting up the KESB. The new law on the protection of children and adults intended to grant those affected more protection against discrimination, guarantee the proportionality of welfare measures and strengthen their right to self-determination. At the same time, the lay authority was replaced by a professionalized child and adult protection authority (KESB). ${ }^{6}$

The qualitative analysis of the public discourse is drawn on a broad sample of different types of media (for example articles from high-circulation regional and national daily and weekly newspapers). The political discourse will be analyzed by inspecting council documents, reports and official hearings of commissions, protocols of debates in the National- und Ständerat [Swiss National Council and Upper Chamber], and statements by the Federal Council (child protection).

For the qualitative analysis of the expert discourse based on the research perspective of discourse analysis (Keller, 2011a), we gather 25 casefiles per time period, that means before and after the introduction of the KESB, taking into account the different cantonal structures (e.g., languages, religion, population density etc. An overview of diversity in Switzerland and its implication on organization is provided by Jud \& Knüsel, 2019). Sampling includes affected families whose child or children were of school age between 4 and 10 years at the time of the measure taken. ${ }^{7}$ To avoid confirmatory interpretations, sample selection is as broad as possible (Strauss, 1996) and covers different types of families (one-parent families, large families, and families with different socio-economic status backgrounds; i.e. differences in educational qualifications and occupation

\footnotetext{
${ }^{5}$ These structural characteristics are the number of inhabitants, proportion of foreigners, language/mentality/religion, geographical position, political situation/distribution, infrastructure and public transport/ links to the city, economic structure, and historical development.

${ }^{6}$ The introduction of the new child and adult protection authorities was undisputed in Parliament, but the reform was strongly taken up in public debates, especially in the media. In particular, the so-called Flaach case, in which a mother killed her two children in 2015 after the KESB withdrew her custody, triggered a broad media controversy. In 2016, an initiative was submitted which intends to restrict KESB's power. However, efforts have failed at an early stage.

${ }^{7}$ The focus is on school-age children (in Switzerland, compulsory schooling begins with the first kindergarten at the age of four), as this is neglected in both research and practice compared to intensified early fostering. If those effects of early fostering should not stop, the question arises how support can be structured when children transfer to compulsory schooling.
} 
level). To analyze decision-making processes in the current research period, 20 cases are selected based on the method of theoretical sampling, and the decision-making sessions are assessed with non-participant observation. After each of these sessions, the case-related perspective of the decision maker is determined through an expert interview. Observation protocols and data from the other named sources are analyzed case by case and also on a more comprehensive level based on the method of grounded theory (Strauss, 1996). The decisive aspect here will be to focus on the construction of shared norms and values while simultaneously taking account of patterns and structures of interpretation. Hence, this concerns which spaces, which power structures are created by the organization of language; which representations and practices are performed by the participants; and which types of resistance they express (see Parker, 2003).

The perspective of affected mothers ${ }^{8}$ is assessed with problem-centered interviews $(\mathrm{N}=20)$ (Witzel \& Reiter, 2002). The theoretical sampling (Strauss, 1996) is based on the selected files. The perspective of those affected is worked out contrastingly with the method of grounded theory. Whenever possible, assessments are performed in such a way that data on specific cases can be linked together across different data levels.

Finally, we will conduct an in-depth historical and sociological analysis of the two Swiss cantons. Within these analyses, the expert discourse is examined against the background of the political/public discourse both in depth and for a broader time period (1981 to 2019). The chosen time frame ties the project to the research by the UEK (Independent Expert Commission), which studied the history of administrative care in Switzerland until 1981 (e.g., Bühler et al., 2019).

\section{Preliminary Findings}

The great importance of the reconciliation of work and family life becomes visible in the media discourse: Gender aspects are discussed mainly from the perspective of integrating mothers in the labor market, regardless of the political position of the media. Similarly, the topics of family and maternity are primarily discussed in relation to employment and care issues. Interestingly, reconciliation is mainly discussed as a maternal problem and "problem solutions" are predominantly about women. Cross-gender approaches to this remain rare. Parallels can be seen in the political discourse: with regard to family issues, issues of compatibility, care work, and the integration of women and mothers in the labor market are launched as requests in the federal parliament. In addition, there are discussions about the quantitative expansion of extra-familial care, whereas quality issues are seen as a cantonal responsibility. Apparently, a fairer distribution of roles in families is sought, but economic and demographic interests seem to be predominant. The first requests $(1998,2006,2008,2009)$ on paternity/parental leave were decisively rejected by the federal parliament and the Federal Council. Economic arguments were emphasized, reference was made to the 
usual regulation in the Swiss Code of Obligations (OR), and alternative forms such as contractual solutions via social partnerships or the expansion of extra-familial care were suggested. It is astonishing that these debates were hardly taken up by the media in the same period (2009/2010). The Federal Council argued at that time (2009) that the largely "traditional" distribution of roles within the family was changing only slowly, that there was a lack of willingness by the economy to create conditions for a partnership-based distribution of roles, and that the distribution of roles was seen as a private matter of families. However, political positions oscillate, depending on party affiliation, between the concept of the family as a private or public affair. At the same time, in relation to general family issues, advances on childrearing and motherhood are less frequent. These include proposals on maternity protection, sexual and reproductive health of mothers and questions of parenting. We assume that, more so than with general family issues (in the sense of reconciliation issues, external childcare, etc.), childrearing and motherhood are regarded as genuinely private issues in which the state has not to interfere.

Concerning family images, social change is also reflected in parliamentary debates-a greater diversity of family forms is recognized, even if the "traditional" family model seems to prevail. Equality for homosexual couples remains only partially enforceable. Changes in gender equality is a major theme in the media, especially in the period 2018/2019, and, depending on the type of media, will be presented as threatening, as a description of facts, or as a gain. Similarly, family images oscillate between "traditional" and breaking up traditional family images. Alternative family forms are taken up in particular in connection with reproductive medical possibilities, and here, too, depending on the type of media and political positioning, are presented as a threat or as a description of a phenomenon. In principle, family is perceived from the perspective of "social change" and understanding of the needs and difficulties of parenthood seems increasingly gaining ground in a temporal comparison. Above all, the increased criticism of child and adult protection authorities is accompanied by a growing empathy for parenthood. In the media discourse, an increasing distancing from physical punishment in childrearing becomes apparent over time, while at the same time alternative ways of thinking are discussed primarily in specific journals. Finally, neglect of children is only marginally addressed by the media and politics. Wherever it is addressed, motherhood is in the foreground and "good motherhood" is discussed. In this context, paternity seems secondary or is not discussed at all. In "sensational reports" on child neglect, dirt and the untidy condition of the house become indicators of neglect, while the social context remains marginal.

Against the background of our questions about the impact of normative images of family, childrearing and motherhood on welfare practice, in particular the decision-making process in cases of child neglect, it seems clear that gender categories, especially motherhood, continue to be of great importance. It is not the father, the family, the relatives, or other reference persons that are addressed 
in a primary way, but rather the mother. On the basis of the preliminary analysis of the casefiles one could speak of a "motherism": in case processing and in the course of the case, responsibility is attributed to the mother, and social and pedagogical contexts are neglected. The focus is on the mother's situation, her psychological state and her ability to care for her children, while the financial situation is given less importance in the data material analyzed so far. In the risk assessment reports ${ }^{9}$, but also in the expert interviews, the description of the mother's situation is given more importance with respect to the situation of the child. The focus on living arrangements, furnishings and cleanliness is also striking. These topics also frequently appear in the media as indicators of child neglect. The willingness to cooperate is often a key factor in deciding on further interventions. Other studies have also highlighted the importance of parents' willingness to cooperate in the decision-making process (for a critical view see Jud \& Gartenhauser, 2015). Furthermore, it can be seen that in decision-making processes with far-reaching consequences (e.g., placement of a child in out-of-home care) legal arguments are preferred, while childrearing aspects are neglected. In reports, the lack of reflection on the significance of the pressure by the authority on the family and the resulting cooperation or adaptation is striking. Likewise, normative and sometimes stigmatizing statements do not belong to the past.

Similarly, to the historical results of the UEK (Independent Expert Commission) (see Bühler et al., 2019: p. 229ff), the material shows that the files, expert's opinions, and reports are of great importance in the decision-making process. The risk assessment reports are often regarded as social reality (and not as a construction) and the patterns of interpretation are adopted in the argumentation. In contrast, the observations of the decision-making sessions, in contrast to the UEK final report, so far show that the individual cases are given sufficient time and space for differentiated arguments in the session. The inclusion of affected persons and the work towards successful cooperation are also central goals of the professional work.

\section{Conclusion}

Child neglect is an ongoing social problem. The knowledge gained in this project will contribute to making the involved professionals more aware and it will shed light on the consequences of unjust and prejudiced interventions for the biographies of those subjected to them. Reflecting on the images of family, childrearing, and motherhood can contribute to preventing arbitrary decisions and thereby counter the reproduction of hegemonic societal structures. This is becoming particularly necessary in light of the rapid social changes in the spheres

${ }^{9}$ In Switzerland, a decision on a child protection intervention is preceded by a risk assessment. It may be provided by a field worker in a general social service or by a service specialized on risk assessments for child protection authorities. The risk assessment proceedings comprise several weeks and include meetings with the child and its family in the field worker's office and home visits. At the end of this assessment, the field worker summarizes his or her findings in a report for the child protection authority, together with recommendations on interventions to be taken if necessary (Jud \& Knüsel, 2019). 
of family, motherhood, and fatherhood due to advances in reproductive medicine and the accompanying erosion of biological motherhood. This reveals the urgent need for both a legal and a social-scientific discourse on motherhood (see Special Issue 2/2017 of the journal Praxis der Rechtspsychologie entitled "Neue Elternschaften" [New parenthoods], further Eggen, 2018; Kannegiesser \& Reichert, 2019; Sanders, 2020). Furthermore, the project will deliver a systematic reconstruction and analysis of the discourse on family, childrearing, and motherhood that takes account of its historical and social contingencies. This will fill a central gap in research that has been identified in the academic discourse. A significant aspect is the targeted linking together of the three concepts and the consideration of their intertextual entanglement while integrating the impact of social change on welfare practice. The project will contribute to gaining knowledge about the interactions between discourses in the decision-making processes, to determining which norms and values are decisive for decision makers, and to contrasting these with the subjective outlook of affected mothers. Finally, the project will generate knowledge about the significance of the gender order in child neglect and clarify how this relates to the socio-structural situation of those affected. It allows to think about care and the design of this unpaid work in our society and not viewing child neglect as a primarily social problem of mothers. ${ }^{10}$ This is significant in so far as social and economic changes will probably lead to an increase in the problem of delivering private care work (on the problem of the "double blurring of boundaries" and the accompanying strain on families, see Jurczyk, 2014: pp. 172 ff).

\section{Acknowledgements}

This study is funded by the Swiss National Science Foundation.

\section{Conflicts of Interest}

The authors declare no conflicts of interest regarding the publication of this paper.

\section{References}

Affolter-Fringeli, K., \& Vogel, U. (2016). Kommentar zum schweizerischen Privatrecht (Berner Kommentar), Das Zivilgesetzbuch, Die elterliche Sorge/der Kindesschutz, Art. 296-317 ZGB, Das Kindesvermögen, Art. 318-327 ZGB, Minderjährige unter Vormundschaft, Art. 327a-327c ZGB. Bern: Stämpfli.

Aichhorn, A. (1951). Verwahrloste Jugend. Die Psychoanalyse in der Fürsorgeerziehung (9th ed.). Bern: Huber.

Alberth, L., \& Bühler-Niederberger, D. (2017). The Overburdened Mother: How Social Workers View the Private Sphere. In T. Betz, M.-S. Honig, \& I. Ostner (Eds.), Parents in the Spotlight: Parenting Practices and Support from a Comparative Perspective (pp. 153-170). Opladen: Verlag Barbara Budrich. https://doi.org/10.3224/zff.si11y2016/2017.09

Atzbacher, E. (2010). Hilflose Fürsorge? Das Vormundschaftswesen und die illegitimen

${ }^{10}$ The problem also has to be perceived globally because of transnational care chains. 
Mutterschaften lediger Frauen in St. Gallen (1930-1950). In G. Hauss, \& B. Ziegler (Eds.), Helfen, Erziehen, Verwalten. Beiträge zur Geschichte der Sozialen Arbeit in St. Gallen (pp. 205-223). Zürich: Seismo.

Aulenbacher, B. (2009). Die soziale Frage neu gestellt-Gesellschaftsanalysen der Prekarisierungs-und Geschlechterforschung. In R. Castel, \& K. Dörner (Eds.), Prekarität, Abstieg, Ausgrenzung. Die soziale Frage am Beginn des 21. Jahrhunderts (pp. 65-77). Frankfurt, New York: Campus.

Bauer, P., \& Wiezorek, C. (2017). Familienbilder zwischen Kontinuität und Wandel. Analysen zur (sozial-)pädagogischen Bezugnahme auf Familie. Weinheim, Basel: Beltz Juventa.

Bericht des Bundesrates in Erfüllung des Postulats Fehr (2012). Gewalt und Vernachlässigung in der Familie: notwendige Massnahmen im Bereich der Kinder- und Jugendhilfe und der staatlichen Sanktionierung. Bern: Schweizerische Eidgenossenschaft.

Björkhagen Turesson, A. (2020). Conceptions, Norms, and Values in the Work of Child Protective Services with Families at Risk: An Analysis of Social Workers' Diaries. Clinical Social Work Journal, 48, 369-379. https://doi.org/10.1007/s10615-019-00720-4

Braun, R. (1970). Sozio-kulturelle Probleme der Eingliederung italienischer Arbeitskräfte in der Schweiz. Erlenbach-Zürich: Eugen Rentsch Verlag.

Bühler, R., Galle, S., Grossmann, F., Lavoyer, M., Mülli, M., Neuhaus, E., \& Ramsauer, N. (2019). Ordnung, Moral und Zwang. Administrative Versorgungen und Behördenpraxis. Vol. 7 (Veröffentlichungen der unabhängigen Expertenkommission (UEK) Administrative Versorgungen, Ed.). Zürich: Chronos.

Castel, R. (2008). Die Metamorphosen der sozialen Frage. Eine Chronik der Lohnarbeit (2nd ed.). Konstanz: UVK. (1995)

Castel, R., \& Dörre, K. (2009). Prekarität, Abstieg, Ausgrenzung. Die soziale Frage am Beginn des 21. Jahrhunderts. Frankfurt, New York: Campus.

Cyprian, G., \& Heimbach-Stein, M. (2003). Familienbilder: Interdisziplinäre Sondierungen. Opladen: Leske + Budrich.

Drake, B., \& Jonson-Reid, M. (2014). Poverty and Child Maltreatment. In J. E. Korbin, \& R. D. Krugman (Eds.), Handbook of Child Maltreatment (pp. 131-148). Heidelberg, New York, London: Springer. https://doi.org/10.1007/978-94-007-7208-3_7

Eggen, B. (2018). Multiple Elternschaft-Zur neuen Normalität von Elternschaft. Rpsych, 2, 181-207. https://doi.org/10.5771/2365-1083-2018-2-181

Fegter, S., Kessl, F., Langer, A., Ott, M., Rothe, D., \& Wrana, D. (2015). Erziehungswissenschaftliche Diskursforschung. Theorien, Methodologien, Gegenstandskonstruktionen. In S. Fegter, F. Kessl, A. Langer, M. Ott, D. Rothe, \& D. Wrana (Eds.), Erziehungswissenschaftliche Diskursforschung. Empirische Analysen zu Bildung-und Erziehungsverhältnissen (pp. 9-55). Wiesbaden: Springer. https://doi.org/10.1007/978-3-531-18738-9

Fluke, J. D., López, M. L., Benbenishty, R., Knorth, E. J., \& Baumann, D. J. (2020). Decision-Making and Judgment in Child Welfare and Protection: Theory, Research and Practice. Oxford: University Press.

https://doi.org/10.1093/oso/9780190059538.001.0001

Foucault, M. (2015). Archäologie des Wissens (17th ed.). Frankfurt am Main: Suhrkamp. (1969)

Galm, B., Hees, K., \& Kindler, H. (2010). Kindesvernachlässigung-verstehen, erkennen, helfen. München: Reinhardt.

Gudjons, H. (1995). Pädagogisches Grundwissen (4th ed.). Bad Heilbrunn: Klinkhardt. 
Hammerschmidt, P., \& Sagenbiel, J. (2011). Die Soziale Frage zu Beginn des 21. Jahrhunderts (Vol. 2). Neu-Ulm: AG SPAK Bücher.

Hauss, G. (2012). Die alltägliche Praxis der St. Galler Vormundschaft. Kinder, Jugendliche und Erwachsene unter fürsorglicher Kontrolle. In G. Hauss, B. Ziegler, K. Cagnazzo, \& M. Gallati (Eds.), Eingriffe ins Leben. Fürsorge und Eugenik in zwei Schweizer Städten (1920-1950) (pp. 41-85). Zürich: Chronos.

Herriger, N. (1987). Verwahrlosung. Eine Einführung in Theorien sozialer Auffälligkeit (2nd ed.). München: Juventa.

Jenzer, S. (2014). Private Erziehungsheime für junge Frauen und die Anfänge des Sozialstaates in der Deutschschweiz, 1870er bis 1930er Jahre. Hinweise zur Delegation von Aufgaben und Kompetenzen an private Heime. In M. Furrer, K. Heiniger, T. Huonker, S. Jenzer, \& A.-F. Praz (Eds.), Fürsorge und Zwang: Fremdplatzierung von Kindern und Jugendlichen in der Schweiz 1850-1980 (pp. 159-168). Basel: Schwabe.

Jud, A., \& Gartenhauser, R. (2015). The Impact of Socio-Economic Status and Caregiver Cooperation on School Professionals' Reports to Child Protection Services in Switzerland. European Journal of Social Work, 18, 340-353.

https://doi.org/10.1080/13691457.2014.933093

Jud, A., \& Knüsel, R. (2019). Structure and Challenges of Child Protection in Switzerland. In L. Merkel-Holguin, J. D. Fluke, \& R. D. Krugman (Eds.), National Systems of Child Protection. Understanding the International Variability and Context for Developing Policy and Practice (Vol. 8, pp. 207-227). Berlin: Springer.

https://doi.org/10.1007/978-3-319-93348-1_11

Jurczyk, K. (2014). Entgrenzte Arbeit und Care in privaten Lebensformen. In B. Aulenbacher, \& M. Dammayr (Eds.), Für sich und andere sorgen. Krise und Zukunft von Care in der modernen Gesellschaft (pp. 171-182). Weinheim, Basel: Beltz Juventa.

Kannegiesser, A., \& Reichert, C.-S. (2019). Pluralisierung von Elternschaft. In R. Volbert, A. Huber, A. Jacob, \& A. Kannegiesser (Eds.), Empirische Grundlagen der familienrechtlichen Begutachtung (pp. 114-137). Göttingen Hogrefe.

Keller, R. (2011a). Diskursforschung. Eine Einführung für SozialwissenschaftlerInnen (4th ed.). Wiesbaden: VS Verlag.

Keller, R. (2011b). Wissenssoziologische Diskursanalyse: Grundlegung eines Forschungsprogramms (3rd ed.). Wiesbaden: VS Verlag.

Kessl, F. (2011). Diskursanalytische Vorgehensweise. In G. Oelerich, \& H.-U. Otto (Eds.), Empirische Forschung und Soziale Arbeit (pp. 313-322). Wiesbaden: VS Verlag. https://doi.org/10.1007/978-3-531-92708-4_22

Kortendiek, B. (2010). Familie: Mutterschaft und Vaterschaft zwischen Traditionalisierung und Modernisierung. In R. Becker, \& B. Kortendiek (Eds.), Handbuch Frauenund Geschlechterforschung (pp. 442-453). Wiesbaden: VS Verlag. https://doi.org/10.1007/978-3-531-92041-2_53

König, T. (2014). Diskurstheorie als Werkzeugkiste. Zur Analyse von geschlechtlichen Selbstverhältnissen. In C. Behnke, D. Lengersdorf, \& S. Scholz (Eds.), WissenMethode-Geschlecht: Erfassen des fraglos Gegebenen (pp. 162-173). Wiesbaden: VS Verlag. https://doi.org/10.1007/978-3-531-19654-1_11

Lutz, R. (2014). Soziale Erschöpfung. Kulturelle Kontexte sozialer Ungleichheit. Weinheim, Basel: Beltz Juventa.

Munro, E. (2019). Decision-Making under Uncertainty in Child Protection: Creating a Just and Learning Culture. Child \& Family Social Work, 24, 123-130. https://doi.org/10.1111/cfs.12589 
Parker, I. (2003). Die diskursanalytische Methode. In U. Flick, E. von Kardorff, \& I. Steinke (Eds.), Qualitative Forschung. Ein Handbuch (2nd ed., pp. 546-556). Reinbek bei Hamburg: Rowohlt.

Pomey, M. (2015). Fremdunterbringung von Kindern: Zur Entscheidungsrelevanz normativer Ordnungen von Elternschaft. neue praxis (pp. 149-159). Zeitschrift für Sozialarbeit, Sozialpädagogik und Sozialpolitik, Sonderheft 12 (Neue Aufmerksamkeiten für Familie. Diskurse, Bilder und Adressierungen in der Sozialen Arbeit).

Pomey, M. (2017). Vulnerabilität und Fremdunterbringung. Eine Studie zur Entscheidungspraxis bei Kindeswohlgefährdung. Weinheim, Basel: Beltz Juventa.

Ramsauer, N. (2000). Verwahrlost Kindswegnahmen und die Entstehung der Jugendfürsorge im schweizerischen Sozialstaat 1900-1945. Zürich: Chronos.

Richter, R. (2009). Familienbilder-Möglichkeiten der empirischen Bestimmung. In O. Kapella, C. Rille-Pfeiffer, M. Rupp, \& N. F. Schneider (Eds.), Die Vielfalt der Familie. Tagungsband zum 3. Europäischen Fachkongress Familienforschung (pp. 93-102). Opladen, Farmington Hills: Barbara Budrich. https://doi.org/10.2307/j.ctvdf0d8j.10

Rietmann, T. (2013). Liederlich und Arbeitsscheu. Die administrative Anstaltsversorgung im Kanton Bern (1884-1981). Zürich: Chronos.

Rühle, O. (1971). Illustrierte Kultur-und Sittengeschichte des Proletariats. Frankfurt: Verlag Neue Kritik. (1930)

Sanders, A. (2020). Woher-wohin Familien(recht) im Wandel. Rpsych, 3, 407-421. https://doi.org/10.5771/2365-1083-2020-3-407

Schweizerische Gesellschaft für Pädiatrie SGP (2017). Nationale Kinderschutzstatistik 2016.

http://www.swiss-paediatrics.org/sites/default/files/nationale_kinderschutzstatistik_201 6_d.pdf

Strauss, A., \& Corbin, J. (1996). Grounded Theory: Grundlagen Qualitativer Sozialforschung. Weinheim: Psychologie Verlags Union.

Taylor, B., \& Whittaker, A. (2020). Professional Judgement and Decision Making in Social Work: Current Issues. New York: Routledge. https://doi.org/10.4324/9780429058721

Tolasch, E. (2016). Die protokollierte gute Mutter in Kindstötungsakten. Theorie und Praxis der Diskursforschung. Wiesbaden: Springer. https://doi.org/10.1007/978-3-658-11288-2

Tolasch, E., \& Seehaus, R. (2017). Mutterschaften sichtbar machen. Sozial-und kulturwissenschaftliche Beiträge. Opladen, Berlin, Toront: Barbara Budrich. https://doi.org/10.2307/j.ctvddzgf2

Turney, D. (2000). The Feminizing of Neglect. Child and Family Social Work, 5, 47-56. https://doi.org/10.1046/j.1365-2206.2000.00146.x

Vogel Campanello, M. (2018). Ich hatte zuerst Angst, wenn ich eine Familienbegleitung in Anspruch nehme, dass das heisst, ich versage, ich bin keine gute Mutter (...). Mutterschaft und Fürsorge unter erschwerten Bedingungen. Soziale Passagen. Journal für Empirie und Theorie, 10, 67-84. https://doi.org/10.1007/s12592-018-0283-8

Vogel Campanello, M. (2019). Zwischen Arbeit und Familie. Fürsorge und Erziehung schulpflichtiger Kinder unter prekären Bedingungen. Schweizerische Zeitschrift für Soziale Arbeit, 24, 34-57.

Witzel, A., \& Reiter, H. (2002). The Problem-Centred Interview: Principles and Practice. Los Angeles, CA: Sage. 